\title{
Additional requirement to the Swedish nearly zero energy requirements
}

\author{
Asa Wahlström ${ }^{1,2^{*}}$, and Mari-Liis Maripuu ${ }^{2}$ \\ ${ }^{1}$ Lund University, Building Services, 22100 Lund, Sweden \\ ${ }^{2}$ CIT Energy Management, 41288 Göteborg, Sweden
}

\begin{abstract}
This study has analysed which options would be appropriate to use as additional requirements to the main requirement of primary energy number in the new Swedish building regulations. The starting point is to ensure that buildings are built with good qualitative properties in terms of the building envelope so that low energy use can be maintained throughout the life of the building despite changes in installation systems or the building's occupancy. The additional requirements should aim to minimize energy losses, i.e., to ensure that the building's total energy demand is low. The following possible additional requirements have been examined: net energy demand, net energy demand for heating, heat power demand, heat loss rate and average heat transfer coefficient. In order to ensure that the additional requirements will work as desired and to explore possibilities with, and identify the consequences of, the various proposals, calculations have been made for four different categories of buildings: single-family houses, apartment buildings, schools and offices. The results show that the suggested option net energy demand will not contribute to any additional benefits in relation to primary energy number. The other options analysed have both advantages and disadvantages and it is difficult to find a single additional requirement that fulfils all the pre-set demands.
\end{abstract}

\section{Introduction}

On September 1, 2020, Sweden's new nearly zero energy requirements for new constructions came into full force. These are based on the revised Energy Performance Directive (2018/844/EU), which allows that the primary energy requirements are based on weighting factors. The system boundary for the requirements is delivered energy to the building. However, the Energy Commission, a government public inquiry, has assessed that the system boundary instead should focus on building's energy demand and have requirements on net energy demand of a building [1]. The purpose with requirements based on net energy demand is to ensure that a building has good qualitative properties in terms of the building's envelope so that good energy management can be maintained throughout the life of the building despite changes in the building's services systems or changes in the building's occupancy. While todays primary energy requirement ensures a good energy management of the entire building, i.e., the building's envelope together with the building services systems and users' activities.

The Swedish Government has therefore commissioned the Swedish National Board of Housing, Building and Planning in cooperation with the Swedish Energy Agency to take forward a proposal on how to design an additional requirement based on the building's energy demand, i.e., net energy demand of the building, taking into account socio-economic consequences [2].
In this study we have taken forward some basic grounds for the authorities' commission in addition to follow-up of the previously made studies [3].

\subsection{Aim and limitations}

This study has analysed which options would be appropriate to use as additional requirements to the main requirement of primary energy in the Swedish new building regulations. The starting-point has been to take a broader approach and to investigate several options of additional requirements and not just net energy demand of the building. The purpose is to ensure that buildings are built with good property requirements in terms of the building envelope and therefore the additional requirements need to ensure that the building envelope is well insulated, has minimal thermal bridges, a good air tightness and also that ventilation losses are minimized. The additional requirement should ensure that energy losses are minimized, i.e., that the building's energy demand is low.

This study does not intend to make any proposals for limit values or levels that may be appropriate in relation to primary energy level requirements, but merely intends to explore possibilities with, and identify the consequences of, the various proposals for additional requirements.

\footnotetext{
* Corresponding author: Åsa Wahlström, asa.wahlstrom@hvac.lth.se
} 


\section{Method}

A number of possible additional requirements were first identified through a literature review and interviews with industry stakeholders. The selected additional requirements were thereafter analysed for different type buildings.

In order for an additional requirement to be appropriate to apply, it needs to have the following qualities:

- reward a building design that reduces the building's energy demand,

- $\quad$ is expressed as functional requirement,

- $\quad$ is verifiable by measurement,

- $\quad$ is formulated in the same way for different building categories.

The first point means that the additional requirement should have a significant impact on the building's qualitative properties in terms of reducing energy losses through transmission, infiltration and ventilation. The aim of this study is primarily to analyse whether the various alternative additional requirements can ensure that the building has a building envelope with good insulation capacity, minimal thermal bridges, a good air tightness and that windows are oriented or shielded so that overtemperatures or a high cooling requirement do not occur in summer.

The other points are answered from the experience and responses of industry stakeholders in interviews and workshops. No specific study of how the various additional requirements is to be verified with the measurement plan has been carried out in this study.

Furthermore, the additional requirement needs to be a complement to the main requirement on primary energy. It is also beneficial if the additional requirement can be calculated in a relatively simple way, is easy to understand, is related to practical application and is possible to be used both in new construction and in case of refurbishment.

The following possible additional requirements have been examined: net energy demand (total energy demand), net energy demand for heating, heat power demand according to Swedish certification system Miljöbyggnad, heat loss rate according to Swedish passive house criteria Feby and average heat transfer coefficient, $U_{m}$.

In order to ensure that the additional requirements will work as desired and to explore possibilities with, and identify the consequences of, the various proposals, calculations have been made for four different categories of buildings: single-family houses, apartment buildings, schools and offices. For each building category, a base case was designed based on commonly occurring constructions, geometries and floor plans so that requirements, within the building regulations, for primary energy and average heat transfer coefficient $\left(U_{m}\right)$ were just fulfilled. For all base cases different heating systems were tested (district heating, ground source heat pump, bio-fuel boiler and exhaust air heat pump). All base cases had balanced mechanical ventilation with heat recovery, except for the cases with exhaust air heat pump. The ventilation systems in the base cases were constant air volume ventilation, which were regulated after operating hours in the school and office building.

From the base case in each building category, two additional cases have been studied. A so-called lowenergy building with a better U-value of the components of the building envelope, better air tightness and better heat recovery of the ventilation compared to the base case. In the school building case also variable air volume ventilation were analysed for the low-energy case. The second case is a change in the building's form factor but with the same heated area $\left(\mathrm{A}_{\text {temp }}\right)$ and the same $\mathrm{U}$-values on building envelope components. As a result, a total of 12 case study buildings have been analysed in four different climate locations in Sweden: Linköping, Malmö, Östersund and Gällivare [4].

\subsection{Main requirement on a building's energy performance}

It is delivered energy (energy use) that is the system boundary for the building's energy performance in the Swedish National Board of Housing, Building and Planning's building regulations (BBR). The delivered energy includes annual energy supplied to a building for heating, comfort cooling, domestic hot water production and electricity for the operation of the building. Household electricity in dwellings or electricity for business activities in premises is not included. The national building regulations allow energy use to be reduced by energy generated on site from solar, wind, ground, air or water and used for the building's heating, comfort cooling, hot water and operational electricity. The delivered energy should be adjusted for a normal metrological year and for normal use by the users when a building's energy performance is determined.

Since July 2017, the building's energy performance is described as a primary energy number with the unit $\mathrm{kWh} / \mathrm{m}^{2}$ and year. According to the Swedish building regulations BBR [5], which entered into force on 1 September 2020, the primary energy number of the building shall be calculated by dividing the delivered energy for different energy carriers and multiplying by a weighting factor per energy carrier, see Equation 1. Energy to heating is corrected with a geographical adjustment factor $\left(\mathrm{F}_{\text {geo }}\right)$.

$$
E P_{\text {pet }}=\frac{\sum_{i=1}^{6}\left(\frac{E_{\text {heat }, i}}{F_{\text {geo }}}+E_{\text {cool }, i}+E_{D H V . i}+E_{\text {el. } i}\right) * V F_{i}}{A_{\text {temp }}}
$$

Where:

- $E P_{\text {pet }}$ is the building's primary energy $\left(\mathrm{kWh} / \mathrm{m}^{2}\right.$ and year)

- $\quad E_{\text {heat }}$ is energy for heating, (kWh/year)

- $F_{g e o}$ is geographical adjustment factor

- $E_{\text {cool }}$ is energy for comfort cooling (kWh/year)

- $E_{D H W}$ is energy for domestic hot water (kWh/year)

- $E_{e l}$ is operational electricity (kWh/year) 
- $\quad V F$ is the weighting factor per energy carrier $i$ (see Table 1)

- $A_{\text {temp }}$ is the heated area of the building $\left(\mathrm{m}^{2}\right)$

Table 1. Weighting factors for calculation of primary energy according to the Swedish building regulations BBR.

\begin{tabular}{|c|c|}
\hline Energy carrier & Weighting factor \\
\hline Electricity & 1.8 \\
\hline District heating & 0.7 \\
\hline District cooling & 0.6 \\
\hline Bio fuels & 0.6 \\
\hline
\end{tabular}

Table 2 shows the requirements on the maximum primary energy number according to the national building regulations BBR.

Table 2. Requirements of primary energy number according to the Swedish building regulations BBR29.

\begin{tabular}{|c|c|}
\hline Building category & $\begin{array}{c}\text { Maximum primary } \\
\text { energy number } \\
\left(\mathrm{kWh} / \mathrm{m}^{2} \text { and year }\right)\end{array}$ \\
\hline Single-family houses $>130 \mathrm{~m}^{2}$ & 90 \\
\hline Multifamily houses & 75 \\
\hline Non-residential buildings & 70 \\
\hline $\begin{array}{c}\text { Non-residential buildings with } \\
\text { maximum addition for } \\
\text { ventilation }\end{array}$ & 96 \\
\hline
\end{tabular}

The ventilation system in dwellings and premises should be designed for an outdoor ventilation rate of 0.35 litres per second and square meter. If, for hygienic reasons, the outdoor ventilation flow in premises is greater than 0.35 litres per second and square meter, an addition may be allowed to the energy performance requirement shown in table 2 . The addition is calculated according to Equation 2. The addition applies for nonresidential buildings and certain residential buildings.

addition $=40 *\left(q_{\text {means }}-0.35\right)$

Where $\mathrm{q}_{\text {means }}$ is the average specific outdoor airflow rate during the heating season and may be credited up to $1,0 \mathrm{l} / \mathrm{s}$ per $\mathrm{m}^{2}$.

\subsection{Additional requirements}

The current national building regulation already has an additional requirement to the main requirement. As an additional requirement to the maximum energy number, a building must also fulfil the requirement on a average heat transfer coefficient $\left(\mathrm{U}_{\mathrm{m}}\right)$, including thermal bridges, see Table 3 .
Table 3. Requirements of maximum average heat transfer coefficient $\left(\mathrm{U}_{\mathrm{m}}\right)$ according to the Swedish building regulations $\mathrm{BBR}$.

\begin{tabular}{|c|c|}
\hline Building category & $\begin{array}{c}\text { Maximum } \mathbf{U}_{\mathbf{m}} \\
\left(\mathrm{W} / \mathrm{m}^{2}, \text { Kelvin }\right)\end{array}$ \\
\hline Single-family houses $>130 \mathrm{~m}^{2}$ & 0,3 \\
\hline Multifamily houses & 0,4 \\
\hline Non-residential buildings & 0,5 \\
\hline
\end{tabular}

A literature review and interviews with the market stakeholders have identified four alternatives to $U_{m}$ as complementary requirements to primary energy number [3].

\subsubsection{Net energy demand}

Net energy demand is the energy emitted directly from the technical systems of the building for heating, comfort cooling, domestic hot water production and appliances in addition to the energy supplement made by passive solar radiation and internal heat supplements from persons.

The Energy Commission report defines net energy demand as the total building's net energy demand and corresponds to the building's final energy demand [1].

\subsubsection{Net energy demand for heating}

The building's net energy demand for heating is the energy directly emitted by the building's heating system to cover heat losses and air leakage through the building's envelope and ventilation losses through exhaust air in addition to the heat gains due to passive solar radiation and internal heat gains from building occupants, lighting and appliances. It is the energy needed for heating in order to maintain the intended indoor climate during heating season.

This study is based on the system boundary for net energy demand for heating where energy recovered within the building may be credited, for example heat recovery from ventilation air. Heating of domestic hot water is not included, but hot water circulation losses that contribute to heating in the building are included.

The definition is in line with a new proposal from the Procurement Authority, which makes recommendations for voluntary requirements for public procurement at a more ambitious level than required by law.

\subsubsection{Heat power demand and heat loss rate}

Both heat power demand and heat loss rate is based on the same basic principle, the total heat power needed for the building during the coldest day of the year in a normal year. The two requirements are used in two different building certification systems, a Swedish system called Miljöbyggnad [6] and a national passive 
house certification system called FEBY [7]. The main difference between the two methods is that in Miljöbyggnad the heat power demand is calculated per building's envelope area, Aenvelope and in FEBY the heating loss rate per building's heated area, $A_{\text {temp. }}$.

\subsubsection{Solar heat load}

In addition to limiting energy needed for space heating, it is also important to limit the need for comfort cooling in buildings with cooling systems and to limit the number of hours where the indoor temperatures exceed the levels for good thermal comfort in buildings without a cooling system. This can be done by limiting heat gains due to solar radiations in order to make sure that systems for solar shading are put in place. The two Swedish certification systems (Miljöbyggnad 3.1 and FEBY18) have in addition to requirements for heat power demand or heat loss rate also requirements for a factor called solar heat load $[6,7]$. The solar heat load is defined as the solar heat power supplied to the room per square meter of floor area. Only windows that face between 90 and $270^{\circ}$, i.e. east to west via south are included in the assessment.

In this current study, calculations have been made for a number of critical rooms in the case study buildings [4].

\section{Results}

Table 4 summarizes the extent to which the various additional requirements analysed in this study meet the desired qualities mentioned in Chapter 2.

Table 4. Degree of fulfilment of qualities for various additional requirements analysed in this study, where green indicates that the qualities are met with high degree, yellow with less deviation, orange has difficulty meeting the quality and red indicates that it can be difficult to meet the quality required.

\begin{tabular}{|c|c|c|c|c|c|}
\hline Qualities & 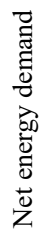 & 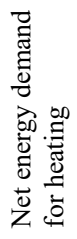 & 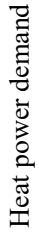 & 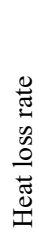 & $\Xi$ \\
\hline $\begin{array}{l}\text { Expressed as } \\
\text { functional } \\
\text { requirement }\end{array}$ & & & & & \\
\hline $\begin{array}{l}\text { Verifiable by } \\
\text { measurement }\end{array}$ & & & & & \\
\hline $\begin{array}{l}\text { Formulated in the } \\
\text { same way for } \\
\text { different building } \\
\text { categories }\end{array}$ & & & & & \\
\hline $\begin{array}{l}\text { Reduces the } \\
\text { building's energy } \\
\text { demand }\end{array}$ & & & & & \\
\hline
\end{tabular}

A good building design means that a building has a building envelope with good insulation capacity, minimal thermal bridges, a good air tightness and that windows are oriented and solar shading used so that temperatures exceeding the levels for good thermal comfort or a high cooling requirement do not occur. Table 5 presents different parameters that contribute to good building design and whether the different options studied as additional requirements for the primary energy number, take these into account.

Table 5. Different parameters that contribute to good building design and whether the main requirement (primary energy number) and the different options for additional requirements take these into account.

\begin{tabular}{|c|c|c|c|c|c|c|c|}
\hline & 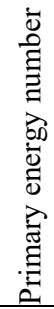 & $\begin{array}{l}\vec{\Xi} \\
\vec{\Xi} \\
\overrightarrow{0} \\
\overrightarrow{0} \\
\overrightarrow{0} \\
\overrightarrow{0} \\
\overrightarrow{0} \\
\overrightarrow{0} \\
\overrightarrow{0}\end{array}$ & 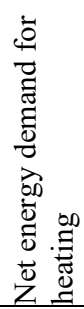 & 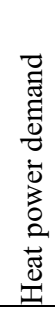 & 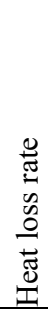 & . & 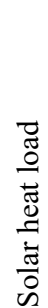 \\
\hline $\begin{array}{l}\text { Transmission } \\
\text { losses }\end{array}$ & $\mathrm{X}$ & $\mathrm{X}$ & $\mathrm{X}$ & $\mathrm{X}$ & $\mathrm{X}$ & $\mathrm{X}$ & \\
\hline $\begin{array}{l}\text { Thermal } \\
\text { bridges }\end{array}$ & $\mathrm{X}$ & $\mathrm{X}$ & $\mathrm{X}$ & $\mathrm{X}$ & $\mathrm{X}$ & $\mathrm{X}$ & \\
\hline $\begin{array}{l}\text { Infiltration } \\
\text { losses }\end{array}$ & $X$ & $\mathrm{X}$ & $\mathrm{X}$ & $\mathrm{X}$ & $X$ & & \\
\hline $\begin{array}{l}\text { Ventilation } \\
\text { losses }\end{array}$ & X & $\mathrm{X}$ & $\mathrm{X}$ & X & $\mathrm{X}$ & & \\
\hline $\begin{array}{l}\text { Building } \\
\text { shape }\end{array}$ & $\mathrm{X}$ & X & $\mathrm{X}$ & & & & \\
\hline $\begin{array}{l}\text { Building } \\
\text { orientation }\end{array}$ & $X$ & X & $X$ & & & & \\
\hline $\begin{array}{l}\text { Passive solar } \\
\text { heating }\end{array}$ & $X$ & $X$ & $X$ & & & & $X$ \\
\hline Cooling need & $X$ & $X$ & & & & & $X$ \\
\hline $\begin{array}{l}\text { Impact to } \\
\text { reduce over- } \\
\text { temperatures }\end{array}$ & & & & & & & $X$ \\
\hline
\end{tabular}

\subsubsection{Net energy demand}

The advantage of net energy demand as an additional requirement to the primary energy number is that it takes into account all the characteristics of the building that affect building's energy demand regardless of the technical system that meets the demand. Net energy demand takes into account both heating and cooling demand in the building.

Calculations with different case study buildings show that reduced heat losses through the building envelope, infiltration and ventilation can save up to $32 \%$ of the total net energy demand depending on the 
building category and geographical location. Steering against reduced energy losses using net energy demand as an additional requirement has a greater impact on residential buildings and school buildings compared to, for example, office buildings. Office buildings often have a significant cooling demand due to high internal loads, which means that building envelope measures reduce the heating demand while increasing the cooling demand and balancing out savings in the total net energy demand.

One disadvantage of net energy demand is that it requires extra meters for verification besides ordinary tariff meters. Comparison with the primary energy number that was also calculated for the case study buildings shows that measures that reduce heat loss through the building envelope, infiltration and ventilation change the primary energy number in percentage almost as much as net energy demand.

\subsubsection{Net energy demand for heating}

The advantage of net energy demand for heating is that it takes into account all the characteristics of the building that affect the building's heat demand regardless of the technical systems that meet the demand. Different measures have a higher percentage impact on the net energy demand for heating compared to building's total net energy demand, which means that even small measures have a clear impact. Calculations with different case study buildings show that better building envelope, air tightness and heat recovery in the ventilation system reduce net energy demand for heating by up to $63 \%$ depending on the building type and geographical location. Net energy demand for heating also takes into account the orientation and form of the building. Especially in single-family houses, the form of the building has a significant impact on net energy demand for heating.

The disadvantage is that requirements on the net energy demand for heating do not take into account that buildings with lower heating demand may have an increased need for comfort cooling. For example, better building envelope and air tightness in the case study office building leads to a reduction in net energy demand for heating of up to $40 \%$. At the same time, the need for cooling is increasing. Verification can also be more complicated since distributed heat needs to be measured in addition to delivered heat energy.

\subsubsection{Heat power demand and heat loss rate}

The advantage of heat power demand and heat loss rate is its direct connection to the building's heat losses through building envelope including thermal bridges, through infiltration and ventilation. Low heat losses mean low energy use (delivered energy) regardless of the type of heating system. Calculations with different case study buildings show that low-energy buildings, with improved construction, air tightness and efficiency of the heat recovery of the ventilation system, reduce heat power demand and heat loss rates with $31-37 \%$ depending on the building category. Heat power demand work well for larger buildings, while the heat loss rate works well for small buildings and it is therefore difficult to express the requirements in the same way for all building categories.

Another advantage is that grading criteria for newly produced houses are well developed for heat power demand according to certification with Miljöbyggnad and for heat loss rate according to the national passive house certification with FEBY. One disadvantage of both methods is that they do not take into account the cooling demand that occurs for example in offices. A low heat power demand or heating loss rate in a building may mean an increased cooling demand. Window orientation also affects the building's heating and cooling demand, which is not reflected by the two factors. Another drawback is that both factors use simplified methods for calculating infiltration, which means that the improvements in air tightness of the building does not have considerable impact on the heat power demand or heat loss rate, while it can have a considerable impact on net energy demand for heating.

Both heat power demand and heat loss rate can be relatively easy measured and verified with a power signature, where the measured power demand for heating is correlated with the outdoor temperatures.

\subsubsection{Average heat transfer coefficient, $U_{m}$}

The National Board of Housing, Building and Planning's building regulations contain requirements for the average heat transfer coefficient $\left(\mathrm{U}_{\mathrm{m}}\right)$ of a building envelope. The requirement for $U_{m}$ is intended to ensure that a building has a certain insulating capacity and thus limit a building's heat loss.

However, $\mathrm{U}_{\mathrm{m}}$ does not take into account heat losses via infiltration or ventilation, which can reduce the overall heat losses as much as improved U-values (for example, in the low-energy case study buildings). Changes in the form of the building may also affect the $\mathrm{U}_{\mathrm{m}}$ value. In several cases, an increased form factor reduces the $U_{m}$ value while increasing heat energy demand and primary energy number. In other words, low $U_{m}$ value is not a direct indicator of low energy demand and low primary energy use. $U_{m}$ is difficult to measure in already constructed building.

\subsubsection{Solar heat load}

Limiting solar heat gains by setting requirements on the solar heat load factor leads to a good solar shading in buildings. The aim is to reduce indoor temperatures exceeding the levels for good thermal comfort and to reduce cooling demand.

In buildings with cooling systems, lower solar heat load can significantly reduce the cooling power demand regardless of the set temperatures used in the the comfort cooling system. Reducing solar heat load leads to a reduced cooling demand while in some cases net energy demand for heating is increasing. As the reduction in 
cooling demand is higher, the total net energy demand of a building will decrease.

In buildings without cooling, a reduction in solar heat load led to marginal changes in the building's energy demand. However, based on the calculations in residential case study buildings, low solar heat load is not a guarantee to avoid problems with overtemperatures during summer time. In addition to solar shading, the orientation of the windows and the possibility of airing with windows have a major impact on avoiding overtemperatures indoors in residential buildings.

The disadvantage is the calculation method where the calculation of aggregated solar factors for window glass and solar shading is quite complicated and depends on the calculation tool used. Verification, however is relatively easy.

\section{Discussion and conclusions}

This study has analysed which options would be appropriate to use as additional requirements to the main requirement of primary energy in the Swedish new building regulations. The results show that none of the options analysed are unambiguous to be used as additional requirements to the main requirement of primary energy number. All of the studied parameters have advantages and disadvantages and it is difficult to find a single additional requirement that fulfils all the pre-set demands: to have a significant impact on reducing building's energy demand, is expressed as a functional requirement, can be easily verified by measurement and is suitable for all building categories.

The analysis of building's net energy demand shows that measures that reduce heat loss through transmission, infiltration and ventilation show similar impact also on primary energy number. An additional requirement expressed in net energy demand will thus not contribute to any additional benefit compared to the main requirement. Thus, net energy demand for heating, heat power demand, heat loss rate or the current average heat transfer coefficient $U_{m}$ are more suitable alternatives. However, for these alternatives some form of additional control is needed to reduce cooling demand, which makes it advisable to add solar heating load as a second supplementary requirement.

The analysis shows that the use of net energy demand for heating as additional requirement can reward measures that reduce heat loss through transmission, infiltration and ventilation and influences the design of the building in terms of its form and orientation. In the further work, it is recommended to primarily analyse whether net energy demand for heating provides sufficient benefits to replace requirements for average heat transfer coefficient $U_{m}$.

If heat power demand or heat loss rate is to be used, better calculation models for infiltration are needed to take into account the impact that infiltration has on buildings heat energy demand. Otherwise, it will not be advantageous to use these two alternatives compared to just demand requirements on $\mathrm{U}_{\mathrm{m}}$.
Several industry stakeholders stated at the interviews that they prefer heat power demand or heat loss rate as an additional requirement to the main requirement of primary energy number, because it can limit the heat power requirements in the buildings during cold winter days. This is because power tariffs are likely to increase in the future as well as power distribution is constrained now. However, an additional requirement for net energy demand for heating or $U_{m}$ will also indirectly limit the building's power requirements cold winter days as the impact on energy demand is a function of the outdoor temperature.

The system boundaries for net energy demand for heating, heat power demand and heating loss rate should also be reviewed to find a way to address the same technology requirements for mechanical heat recovery in the ventilation system and exhaust air heat pumps.

For a full analysis where it can be concluded that the additional requirement has a governing effect on a building design that reduces the building's energy demand, limit values of the additional requirements need to be analysed in relation to limit values of primary energy number.

Requirements on solar heat load need to be investigated further while taking into account that it may need to be supplemented by requirements for possibility for airing with windows in buildings without cooling systems.

The stakeholders that participated in interviews and workshops, the Swedish Energy Agency and the National Board of Housing Building and Planning are greatly acknowledged. The Swedish Energy Agency is acknowledged for financial support.

\section{References}

[1] Government public investigation,

"Kraftsamling för framtidens energi", Energy

Commission Report, SOU 2017:2.

[2] Government descision. "Uppdrag att utreda kompletterande krav i byggreglerna för byggnaders energiprestanda".I2020/01671/E, $11^{\text {th }}$ of June, 2020.

[3] Å. Wahlström,"Analys av nära-nollenergikrav i byggregler. Kompletterande krav", August 2018. www.energymanagement.se/publications

[4] Å. Wahlström and M. Maripuu, "Kompletterande energikrav i byggregler", $30^{\text {th }}$ of December, 2020. www.energymanagement.se/publications

[5] The National Board of Housing, Building and Planning, "Swedish Building Regulations, BBR 29", 2020. Regelsamling för Byggande. Boverkets byggregler BFS 2011:6 med ändringar, BFS 2020:4, 2020.

[6] Swedish Green Building Council, "Miljöbyggnad 3.1", 2020.

[7] FEBY, "Kravspecifikation för energieffektiva byggnader, FEBY 18", January 2018. 